\title{
Off-label marketing: free speech or illegal promotion?
}

We misspelt the name of the law firm that Chad Landmon works for in this Feature (BMJ 2013;346:f320, doi:10.1136/bmj.f320). The correct spelling for the firm is Axinn, Veltrop and Harkinder (not “Axxin, Veltrop and Harkinder”).
Cite this as: BMJ 2013;346:f793

๑ BMJ Publishing Group Ltd 2013 